European journal of American studies

Special Issue: Oslo Conference

\title{
The Christian Nation Debate and the U.S. Supreme Court
}

Mokhtar Ben Barka

\section{(2) OpenEdition \\ Journals}

Electronic version

URL: https://journals.openedition.org/ejas/8882

DOI: $10.4000 /$ ejas.8882

ISSN: 1991-9336

Publisher

European Association for American Studies

Electronic reference

Mokhtar Ben Barka, "The Christian Nation Debate and the U.S. Supreme Court", European journal of American studies [Online], 6-2 | 2011, document 1, Online since 04 April 2011, connection on 08 July 2021. URL: http://journals.openedition.org/ejas/8882 ; DOI: https://doi.org/10.4000/ejas.8882

This text was automatically generated on 8 July 2021 .

Creative Commons License 


\title{
The Christian Nation Debate and the U.S. Supreme Court
}

\author{
Mokhtar Ben Barka
}

1 In the 1980s, born-again Christians burst into the political arena with stunning force. The founding of the Moral Majority in 1979 by Southern Baptist preacher Jerry Falwell placed Protestant evangelicals in the center of the American political stage. ${ }^{1}$ Together with conservative Catholics, Eastern Orthodox, and members of various politicalreligious groups, Protestant evangelicals constitute the Religious Right, also known as the New Christian Right. ${ }^{2}$ Today, the most important Religious Right group is the Virginia Beach-based Christian Coalition, founded by Reverend Pat Robertson in September 1989. The Coalition's announced mission is to provide "a means toward helping to give Christians a voice in their government again."3

2 Against the respect for religious diversity and the constitutional separation of church and state, Religious Right leaders seek to impose their beliefs and practices on the entire society, as evidenced by the conservative domestic and international policies they ardently support. They use a stream of selective biblical quotes to buttress their political positions on a myriad of issues including abortion, homosexuality, marriage, capital punishment, private ownership of guns, public education and the legitimacy of preemptive wars initiated by the U. S. government. The 2004 election of George W. Bush to a second term as president confirmed the extraordinary power of conservative religious issues in determining the campaign's outcome.

3 Religious Right adherents firmly believe that "the United States was established as a Christian nation by Christian people, with the Christian religion assigned as a central place in guiding the nation's destiny." "Since the United States has lost its moral identity as shaped by its founders, they argue, re-creating a "Christian America" is the only solution to society's acute problems. One of the Religious Right's most visible spokesmen, the evangelist-psychologist James Dobson, distributes through his organization Focus on the Family a set of history lessons that seeks to show that "the Constitution was designed to perpetuate a Christian order." ${ }^{5}$ Many of America's disorders, Dobson says, stem from abandoning this unity of state and church. Another 
well-known Christian conservative leader, Beverly LaHaye, chair of Concerned Women of America, affirms that "America is a nation based on biblical principles... Christian values dominate our government. Politicians who do not use the bible to guide their public and private lives do not belong in government." 6 To be clear, Religious Right leaders seek to convert the United States into a theocracy, although in their campaign to gain control over all aspects of American life, they constantly reassure the public that they are simply supporting "mainstream values."

4 As the title indicates, this article deals with the ongoing debate concerning the "Christian nation" concept. More specifically, it focuses on the 1892 Church of the Holy Trinity v. United States case for it is frequently cited by Religious Right activists to argue for greater government support of religion and for Bible-based legislation. First, I will look at the historical background of this case. I will then examine the case itself, with a particular emphasis on Justice Brewer's ruling in which he stated that America was "a Christian nation." Finally, I will argue that the Holy Trinity ruling was something of a legal anomaly.

\section{Historical Background}

5 To begin with, we need to note that the United States is a secular nation. The First Amendment to the Constitution (1791) prohibits Congress from making any laws concerning an establishment of religion, or prohibiting the free exercise of religion: "Congress shall make no law respecting an establishment of religion, or prohibiting the free exercise thereof." Thus, at the national, there is to be no religious establishment and individuals are to have religious freedom. The provisions of the First Amendment were eventually held to apply to the individual states as well as the Federal government as a result of the passage of the Fourteenth Amendment (1868). The debates concerning the religious clauses of the First Amendment indicate that there was not just a single viewpoint about church-state relations.

6 More generally, the U.S. Constitution was denounced from the very beginning by its Anti-Federalist opponents as a "godless" document. "This underdocumented and underremembered controversy of 1787-88 over the godless Constitution," Isaac Kramnick and R. Laurence Moore explain, "was one of the most important public debates ever held in America over the place of religion in politics." "The separation of church and state and the role of religion in political life became major issues on the national level in the 1860 s and 1870 s, a period during which nativist sentiments escalated in response to the growing immigrant populations. ${ }^{8}$ Several Protestant organizations pushed for a constitutional amendment that would add some type of endorsement of Christianity to the Constitution. A closer look at the church-state battle in the latter half of the century reveals three main approaches to such issues that were vying to capture the American mind during this time.

71.1 - The National Reform Association (NRA), a coalition formed in 1863 by representatives from eleven Protestant denominations, emphasized the Christian character of the nation and advocated an amendment to the Constitution in such a way that the United States would be permanently and officially aligned with Christianity. In order to rectify what it called the "religious defect" in the U.S. Constitution, the NRA petitioned Congress in 1864 to amend the preamble of the Constitution to read, "We, people of the United States, humbly acknowledging Almighty God as the source of all 
authority and power in civil government, the Lord Jesus Christ as the Ruler among the nations [...], do ordain and establish this Constitution of the United States of America." 9 The NRA's amendment had broad support from many prominent citizens, yet it languished in Congress for years, occasionally being reintroduced. Finally in 1874 the House Judiciary Committee voted against its adoption. It was introduced in Congress again in 1882, but this time it died in committee. Another "Christian America" amendment resurfaced nearly one hundred years later, when similar proposals were introduced in Congress in 1961.

8 Alongside the activities of the NRA, religiously conservative ministers attacked the Constitution from the pulpit, usually because it lacked reference to God. These attacks on the Constitution underscore how conservative religious forces have varied their rhetoric against the First Amendment over the years. While in the nineteenth century conservative religious leaders acknowledged the secular nature of the Constitution and called for amending it to include references to God or Christianity, "most Religious Right activists today have abandoned this strategy and in the face of all available evidence insist that the Constitution was somehow written to afford special protection to Christianity." 10

9 1.2- Members of the National Reform Association referred frequently to the persistent demands of the "enemies of our Christian institutions" to eradicate all vestiges of religion from public life. Such epithets referred to the National Liberal League (NLL) and its main spokesman Robert Green Ingersoll, ${ }^{1} 1$ who championed an absolute separation between church and state. The NLL existed to eradicate everything the NRA desired to maintain. To achieve its goals, the National Liberal League, like the National Reform Association, proposed an amendment to the Constitution called the "Religious Freedom Amendment." It had a twofold purpose: to extend to the states the prohibitions of the national Constitution concerning the establishment and the free exercise of religion, and to impose a radical, absolute separation of church and state governments. But it did not gain enough support.

1.3 - While the National Reform Association and the National Liberal League were garnering public support for their opposite positions and vying for the attention of Congress, a third effort toward constitutional change emerged: in 1875, the Republicans proposed the Blaine Amendment which was meant to protect the Protestant domination of American culture and schools to the detriment of minority religions, especially Catholicism. In addition to the exacerbation of the nativist sentiments, the Reconstruction period after the Civil War under President Grant's administration had created a legacy of bitterness in the South. The Republicans needed a platform for the 1876 election that would positively affect the greatest number of voters. One solution, proposed by President Grant in 1875, was to focus the attention of the nation on the issues of education and school funding. ${ }^{12}$ By uniting the entire nation in the common cause of improving education, the Republicans could redirect the focus of the country from the failures of Reconstruction to the hope of rebuilding the nation.

11 One of the 1876 presidential hopefuls, Congressman James G. Blaine, recognized the political promise of the school issue and proposed a constitutional amendment in 1875. The party's school agenda, coupled with the Blaine Amendment, served as a vehicle for political gain. One of the main reasons this strategy worked was the anti-Catholic enmity underlying the public school issue during the latter half of the nineteenth 
century. Because Protestant doctrines and values were at the core of the common school system, many Catholics sent their children to parochial schools in order to educate their children according to their beliefs. The Blaine Amendment's main purpose-to prohibit government funding of sectarian schools-directly hurt the Catholic community since most sectarian schools at the time were Catholic. The Blaine Amendment also rekindled anti-Catholic sentiments and suspicions among Protestants.

12 The Blaine Amendment, unlike those of the National Reform Association or the National Liberal League, was seriously considered in both houses of Congress, but it failed to gain the two-thirds needed for it to be passed to the states for ratification. The defeat of the Blaine Amendment did not stop leaders in the Republican Congress from attempting to influence the school funding issue in the states and territories. Washington, one of the several states that came into the Union in 1889, adopted a Blaine-inspired "establishment Clause" into its Constitution.

\section{The Church of the Holy Trinity v. United States}

13 Although none of these amendments met with successful passage, continuous public debates over the church-state relations permeated the thirty five years after the Civil War to the end of the century. The debates culminated in 1892, when the case of the Church of the Holy Trinity $v$. United States came before the Supreme Court of the United States. ${ }^{13}$ Far from being specifically about religion, the Church of the Holy Trinity v. United States was an immigration case: the issue was whether or not hiring a foreigner violated the federal Contract Labor Act of 1885, a law passed by Congress that was designed to limit legal immigration and place restrictions on the ability of American firms to hire laborers from overseas. More precisely, the Act made it illegal for a corporation, among others, "to prepay the transportation, or in any way encourage the importation or migration of any alien... into the United States... to perform labor or service of any kind."

14 In 1887, the Church of Holy Trinity, a Protestant Episcopal Church in the city of New York, had employed Reverend E. Walpole Warren, an English minister to serve as a pastor and rector. The United States Attorney General challenged that employment. The Circuit Court ruled that the Contract Labor Act prohibited the church's contract with Reverend Warren. As Holy Trinity appealed against the Circuit Court's decision, the case eventually arrived at the Supreme Court. The only issue presented to the Supreme Court was whether Holy Trinity had violated the law. The Supreme Court concluded that the purpose of the Act was to prohibit the importation of foreign unskilled persons to perform manual labor and manual services. A Christian, the Court reasoned, is a "toiler of the brain", not a manual laborer; Holy Trinity Church, therefore, was found not to have violated the Act when it secured a contract for the clergyman's employment. Only manual laborers were covered by the act. Whether or not America was a Christian nation was not even at issue in the Holy Trinity case.

15 The case was decided by Justice David Josiah Brewer, who wrote the majority opinion in favor of the English minister. David J. Brewer was born in Smyrna, (now Izmir, Turkey), on June 20, 1837 and died in Washington D.C., on March 28, 1910. ${ }^{14} \mathrm{He}$ was born of Congregationalist missionary parents in Asia Minor and then raised in privilege. After attending Wesleyan and Yale Universities and Albany Law School, he moved to Kansas in the late 1850 s to begin his professional career. There he served on 
the Supreme Court of Kansas (1870-1884) and the Eighth Circuit Court (1884-1889). In 1890, President Benjamin Harrison appointed him to the Supreme Court, where he served as associate justice until his death. In all, he wrote 719 opinions. David J. Brewer was a talented speaker and a prolific writer. His writings included: The Pew for the Pulpit (1897), The United States A Christian Nation (1905).

16 A devout Christian, David J. Brewer derived his entire philosophy, including his views on legal matters, religious liberty, and church-state relations, from his christian convictions. So, his personal religious beliefs provided a basis for understanding his decision in Holy Trinity. Justice Brewer was convinced that the United States owed its prominence among nations to its close connection to the Christian religion. For him, the role of Christianity in America was not only an historical fact but also a present reality. Moreover, he maintained an unwavering belief that the spread of Christianity was essential to the future success and greatness of America. "Clearly," Jay Alan Sekulow points out, "he believed in the ascendancy of Christianity and felt it offered suffering humanity its only hope of ultimate comfort and justice." 15

17 In his Holy Trinity opinion, Justice Brewer wrote that "beyond all these matters no purpose of action against religion can be imputed to any legislation, state or national, because this is a religious people."He then gave a summary of America's religious history and concluded that "this is a Christian nation". Finally, he rhetorically asked "in the face of all these [utterances that this is a Christian nation], shall it be believed that a Congress of the United States intended to make it a misdemeanor for a church of this country to contract for the services of a Christian minister residing in another nation?"16

18 In his ruling, Justice David J. Brewer relied on two arguments to reverse the Circuit Court's decision. First, he argued that the statute was not intended to prohibit the importation of members of the clergy to the United States for the purpose of serving as a pastor of a church. Second, he argued that prohibiting a church from contracting for the services of a foreign pastor would be in complete contradiction to the overwhelming evidence that "this is a Christian nation". In other words, to apply the Contract Labor Act to restrict the Christian religion would be something the government should not be allowed to do.

19 Furthermore, Justice Brewer mentioned several state and national Supreme Court cases that used the Christian heritage of the United States as a rationale to support their decisions. He cited two blasphemy cases in which the Courts stressed that Christianity was the professed religion of the people of their respective states. In the People v. Ruggles (1811), the Court declared that "the people this state, in common with the people of this country, profess the general doctrines of Christianity," and that "the morality of the country is deeply engrafted upon Christianity." ${ }^{17}$ In the second case, Updegraph v. Commonwealth (1824), the Pennsylvania Supreme Court stated that "Christianity, general Christianity, is, and has been, a part of the Common Law of Pennsylvania..." 18 In addition, Brewer made reference to Vidal v. Girard and approvingly quoted Justice Joseph Story's acknowledgment that "the Christian religion is a part of the common law of Pennsylvania." 19 To Justice Brewer, "these, and many other matters which might be noticed, add a volume of unofficial declarations to the mass of organic utterances that this is a Christian nation." ${ }^{20}$ That Justice Brewer believed the "Christian nation" maxim had legal significance is also supported by his subsequent discussion of Holy Trinity in his speeches and writings. 
20 Justice Brewer was, to a large extent, representative of most nineteenth-century jurists for whom religion and the law were intimately connected. Robert Boston goes even further: "the unpleasant truth is that nineteenth-century America was a mild form of Protestant theocracy. In this period, Protestantism was America's de facto established religion." ${ }^{21}$ Effectively, the United States of this period was an overwhelmingly Protestant country: more often than not, its laws reflected general Protestant religious doctrine. This was all the more so as mainstream Protestants - Presbyterians, Episcopalians, Congregationalists - held power and influenced government.

21 The Civil War may have been the impetus for closer ties between church and state. Some ministers in the North were convinced that God had put the nation at war with itself as a form of punishment for excluding Him from the Constitution. They began pressing for legal changes to bring religion and government closer together. Aside from the Civil War, it is important to remember that at this time in history, most laws were local in origin and as such reflected regional religious attitudes and biases. The federal courts rarely involved themselves in church-state matters, which were left chiefly to state legislators, and disputes, if they occurred at all, were resolved by state courts. It should be added that the court decisions that emerged from the states were mostly at odds with religious freedom and separation of church and state.

\section{Justice David J. Brewer's intent: a subject of controversy}

Justice Brewer's famous statement that "this is a Christian nation," has engendered significant commentary within the legal community. Efforts have been made to argue that David J. Brewer used this phrase and related discussion merely to describe the history and culture of the American nation. To this day, historians debate what David J. Brewer meant by the term. It is unclear whether he meant to say the country's laws should reflect Christianity or was simply acknowledging the fact that most Americans are Christians.

23 Justice Brewer may have believed that the United States was officially Christian, but even he failed to use the Holy Trinity case as precedent when given an opportunity. Five years after the Holy Trinity ruling, a dispute arose concerning legalized prostitution in New Orleans. In L'Hote v. New Orleans (1900), the Methodist church challenged a city ordinance allowing prostitution in one area of the city. The church argued that prostitution should be illegal everywhere in New Orleans on the ground that the activity was inconsistent with Christianity" which the Supreme Court of the United States says is the foundation of our government."22 Writing for a unanimous court, Justice Brewer completely ignored the church's argument and upheld the New Orleans policy. Brewer's bypass in this case suggests that he did not mean to imply in Holy Trinity that the United States should enforce the dictates of Christianity by law. Had that been David J. Brewer's intention, he surely would have upheld the Methodists' claim.

24 As previously noted, in 1905 David Brewer published a short book titled The United States A Christian Nation. What he had to say in this book is very interesting:

But in what sense can [the United States] be called a Christian nation? Not in the sense that Christianity is the established religion or the people are compelled in any manner to support it....Neither is it Christian in the sense that all its citizens 
are either in fact or in name Christians. On the contrary, all religions have free scope within its borders. Numbers of our people profess other religions, and many reject all... Nor is it Christian in the sense that a profession of Christianity is a condition of holding office or otherwise engaging in public service, or essential to recognition either politically or socially. In fact, the government as a legal organization is independent of all religions. ${ }^{23}$

The passage strongly suggests that Justice Brewer simply meant that the United States is "Christian" in the sense that many of its people belong to Christian denominations and many of the country's customs and traditions have roots in Christianity. Justice Brewer expounds on this theme for the rest of his ninety-eight-page book, predicting that Christianity will one day unify the American masses and make the United States a leader in world affairs.

What Justice Brewer says in this book is rarely quoted by Religious Right adherents since it seems to be at odds with their view. Similarly, one wonders why the Religious Right never mentions the 1797 treaty with the Islamic nation of Tripoli. Negotiated under President Washington, ratified later by the Senate, and signed by President John Adams, this treaty states that the harmony between the two countries would not be interrupted for religious reasons because the United States "is not in any sense founded on the Christian Religion." ${ }^{24}$ Instead the Religious Right insists that a Christian nation was the original intent of the Founding Fathers, which is, of course, highly debatable. ${ }^{25}$

The Religious Right tends to overlook the fact that Justice David Brewer is an obscure Supreme Court Justice who has never been considered one of the giants of the Court. "Today," confirms Owen M. Fiss, is largely forgotten." ${ }^{26}$ Whatever his views about the United States as a Christian nation, it is important to realize that the concept has never been embraced by the Supreme Court. The Holy Trinity ruling is something of a legal anomaly that has been cited favorably only once by the Supreme Court since it was handed down. Contrary to Jay Alan Sekulow who states that "by interpreting the Contract Labor Act so as to render it inapplicable to Christian ministers, Brewer took an active role in ensuring the future freedom and expansion of religious liberty in the United States," ${ }^{27}$ Robert Boston asserts that "he had no bearing on the type of churchstate relationship the framers intended for this nation." 28

On the other hand, The Church of the Holy Trinity $v$. the United States and an entire string of bizarre nineteenth-century Supreme Court rulings-that upheld segregation of the races, that decreed that women could be barred from practicing law, and that struck down laws designed to end the national scandal of child labor-cannot seriously be considered today as appropriate guidelines for American society. "They are products of their time," Robert Boston points out, "and reflect cultural biases of the era, not solid constitutional law. Most have been relegated to forgotten volumes of legal history where they belonged." ${ }^{29}$ Religious Right activists often try to use these court rulings to "prove" that America is a "Christian nation". The Religious Right looks so fondly on this period because the country at this time was dominated by white male Protestants. It does not say that "these rulings were aberrations that emerged during a period of intolerance and religious persecution." ${ }^{30}$

Another case sometimes cited by "Christian nation" advocates: United States $v$. Macintosh (1931). It concerned an ordained Baptist minister who was denied naturalization because he was unwilling to take an oath swearing that he would bear arms in defense to be morally justified. In the opinion, Justice George Sutherland wrote, "We are a Christian people, according to one another the equal right of religious 
freedom, and acknowledging with reverence the duty of obedience to the will of God." 31 It is however to be noted that the central finding of Macintosh was overturned fifteen years later.

\section{Conclusion}

30 The church-state battle was already well under way during the founding of the American republic in the late $18^{\text {th }}$ century, and it has continued unabated ever since. Despite the Bill of Rights and more than two hundred years of national history, the appropriate role of religion in a religiously pluralistic America has never been fully resolved. But today's battles are much more turbulent than in the past. The wellorganized Christian conservative movement, both its leaders and their supporters who seek to "baptize" America, are politically stronger, more energized, and better financed than ever before in American history. The "Christian nation" project, promoted by the Religious Right is a serious threat to America's social, cultural and religious diversity. Emboldened by a series of recent electoral victories, Religious Right activists are now demanding full control over every aspect of public and private American life.

\section{NOTES}

1. Evangelicals are conservative Protestants who believe in the sole authority of the literal Bible, a salvation only through the acceptance of Christ as Lord and Saviour, a spiritually transformed personal life, and the necessity of proselytizing. They are more than 55 million. For further details, see Douglas A. Sweeny, The American Evangelical Story. A History of the Movement, Grand Rapids, Michigan: Baker Academic, 2005.

2. For a detailed account see Michael Lienesch, Redeeming America: Piety and Politics in the New Christian Right, Chapel Hill and London: University of North Carolina Press, 1993. Clyde Wilcox, Onward Christian Soldiers? The Religious Right in American Politics ( $2^{\text {nd }}$ Edition), Boulder, Colorado: Westview Press, 2000.

3. http://www.cc.org

4. Isaac Kramnick and R. Laurence Moore, The Godless Constitution: The Case against Religious Correctness, New York and London: W. W. Norton and Company, 1997, p. 13.

5. James Dobson in ibid., pp. 22-23.

6. James Rudin, The Baptizing of America. The Religious Right's Plans for the Rest of US, New York: Thunder's Mouth Press, 2006, p. 44.

7. See Isaac Kramnick and R. Laurence Moore, op. cit., p. 28.

8. An increasingly important outsider in American religion during the nineteenth century was the Roman Catholic Church. In 1789, there were about 35,000 Catholics, roughly 60 percent of these in Maryland. By 1830, the total number of Catholics had grown to over 300,000. In the next thirty years, the Catholic population leaped nearly tenfold to over 3,100,000. See Mark A. Noll, A History of Christianity in the United States and Canada, Grand Rapids, Michigan: W. B. Eerdmans, 1992, p. 205. 
9. See Robert Boston, Why the Religious Right Is Wrong about Separation of Church and State, Amherst,New York: Prometheus Books, 2003, p. 103.

1. ${ }^{0}$ Ibid., p. 105.

1. ${ }^{1}$ Robert Ingersoll, one of the most prominent secularists of the nineteenth century, employed his skill at oration for the furtherance of many causes, one of them being the separation of church and state. He was closely associated with the Liberal league, as evidenced by his selection as its presidential candidate in 1880. Later, in 1885, Ingersoll founded the American Secular Union.

1. ${ }^{2}$ Jay Alan Sekulow, Witnessing their Faith. Religious Influence on Supreme Court Justices and Their Opinions, New York: Rowman and Littlefield Publishers, 2006, pp. 129-131.

1. ${ }^{3}$ Church of the Holy Trinity v. United States, 143 U. S. 457 (1892). http://supreme.justia.com/us/ 143/457/case.html

1. ${ }^{4}$ Owen M. Fiss, "Brewer, David Josiah", in Kermit L. Hall et al., The Oxford Companion to the Supreme Court of the United States, New York and Oxford: Oxford University Press, 1992, pp. 89-91.

1. ${ }^{5}$ Jay Alan Sekulow, op. cit., p. 139.

1. ${ }^{6}$ Church of the Holy Trinity v. United States, 143 U. S. 457 (1892), op. cit.

1. ${ }^{7}$ Ibid.

1. ${ }^{8}$ Ibid.

1. ${ }^{9}$ Ibid.

2. ${ }^{\circ}$ Ibid.

2. ${ }^{1}$ Robert Boston, op. cit., p. 97.

2. ${ }^{2}$ L'Hote v. New Orleans, 177 U. S. 587 (1900), http://supreme.justia.com/us/177/587/case.html

2. ${ }^{3}$ David J. Brewer cited in Robert Boston, op. cit., p. 102.

2. ${ }^{4}$ Mark A. Noll, Nathan O. Hatch, and George M. Marsden, The Search for Christian America, Colorado Springs: Helmers and Howard, 1989, p. 131.

2. ${ }^{5}$ See Mark Weldon Whitten, The Myth of Christian America: What You Need to Know About the Separation of Church and State, Macon, Georgia, Smyth \& Helwys Publishing, 1999. Philip Hamburger, Separation of Church and State, Massachusetts \& London, Harvard University Press, 2002.

2. ${ }^{6}$ Owen M. Fiss, op. cit., p. 89.

2. ${ }^{7}$ Jay Alan Sekulow, op. cit., p. 150.

2. ${ }^{8}$ Robert Boston, op. cit., p. 103.

2. ${ }^{9}$ Ibid.

3. ${ }^{\circ}$ Ibid., p. 99.

3. ${ }^{1}$ United States v. Macintosh, 283 U. S. 605 (1931), http://supreme.justia.com/us/283/605/ case.html

\section{INDEX}

Keywords: Christian Nation, Christianity, Circuit Court, Congress, Constitution, Contract Labor Act, Holy Trinity, National Liberal League, National Reform Association, New Christian Right, Religious Right, Supreme Court. 
AUTHORS

MOKHTAR BEN BARKA

Université de Valenciennes et du Haut-Cambraisis 